\title{
KAJIAN KOMPOSISI MEDIA TUMBUH DAN PUPUK SAMPAH KOTA TERHADAP PRODUKTIVITAS BAWANG MERAH DENGAN TEKNIK VERTIKULTUR
}

\author{
Fathurrahman \\ Fakultas Pertanian dan Perikanan, Universitas 17 Agustus 1945 Banyuwangi \\ Email : fatur.untag@gmail.com
}

\begin{abstract}
Technological and industrial advancements and the rapid increase in population, gradually changing the function of agricultural land into housing and industrial complexes. Overcoming the reduction of agricultural land, efforts made by farming vertically or verticulture methods. Shallots are an important vegetable commodity for the community, because of their high economic value and nutritional content. To reduce imports, it is necessary to increase production and quality of shallots through intensification and extensification. The purpose of the study was to determine the effect of the composition of the growing media, the effect of the dose of organic fertilizer in municipal waste, and its interaction with the productivity of shallots with verticulture cultivation techniques. The study was conducted in the experimental area of the Faculty of Agriculture, UNTAG Banyuwangi, using Kooi's house, using a factorial completely randomized design (RAL) method with four replications consisting of two factors: the composition of the growing media and the dose of municipal waste fertilizer.Growth media composition factor $(\mathrm{M})$ consists of 3 treatments, namely: $\mathrm{M} 1=$ soil: sand: husk ( 2 : 1: 1); M2 = soil: sand: stem of fern (2: 1: 1); and M3 = soil: sand: cocopeat (2:1:1). The composition of municipal solid waste $(\mathrm{P})$ consists of 3 treatments, namely: $\mathrm{P} 1=$ composition of municipal solid waste organic fertilizer $25 \%$; $\mathrm{P} 2=$ composition of city organic waste $50 \%$; and $\mathrm{P} 3=$ composition of urban organic waste $75 \%$. Observation parameters in this study were Plant Height $(\mathrm{cm})$, Number of Leaves, Wet Weight (grams), Number of Tubers, and Tuber Diameter $(\mathrm{cm})$.
\end{abstract}

\section{Keywords: Verticulture, Shallots, Municipal waste fertilizer}

\section{PENDAHULUAN}

Pekarangan merupakan area tanah yang berdekatan dengan sebuah bangunan. Halaman rumah atau pekarangan bisa terletak di belakang, samping maupun depan sebuah bangunan gedung maupun rumah, tergantung dengan seberapa luas sisa area tanah yang tersedia setelah bangunan utama didirikan. Budidaya sayuran di pekarangan bukan hal baru bagi masyarakat. Penggunaan pekarangan sebagai tempat untuk budidaya tanaman sudah lama dilakukan terutama di pedesaan. Namun, seiring berjalannya waktu kebiasaan tersebut kini telah ditinggalkan dan banyak halaman pekarangan yang tidak digunakan dengan baik. Berbeda dengan kecenderungan di atas, jumlah penduduk yang terus mengalami peningkatan menyebabkan kebutuhan bahan panganpun mengalami peningkat. Dalam memenuhi kebutuhan pangan tersebut menemukan berbagai kendala diantaranya yaitu penyempitan lahan pertanian akibat dari pengalihanfungsi lahan untuk bidang non pertanian, perubahan iklim global yang berpengaruh pada tingkat produksi dan distribusi bahan pangan, serta terjadinya peningkatan degradasi lahan sehingga menyebabkan hasil panen yang berkurang. Maka dari itu diperlukan siasat terbaru untuk 
memenuhi kebutuhan bahan pangan melalui penggunaan halaman rumah atau lahan pekarangan. Salah satu cara yang dapat digunakan adalah dengan budidaya tanaman secara vertikultur.

Siswadi (2015) menjelaskan bahwa kemajuan teknologi dan industri serta peningkatan penduduk yang pesat, lambat laun mengubah fungsi lahan pertanian menjadi kompleks perumahan maupun industri. Untuk mengatasi berkurangnya lahan pertanian, salah satu cara yang dapat dilakukan yaitu dengan cara bercocok tanam secara vertikal atau metode vertikultur.

Teknik vertikultur dapat dilakukan di pekarangan yang sempit, bahkan di rumah yang tidak memiliki pekarangan sedikitpun. Penanaman secara vertikultur dapat dijadikan alternatif bagi masyarakat yang tinggal di perkotaan yang memiliki lahan sempit ataupun tidak memiliki lahan. Jenis tanaman yang dapat dibudidayakan dengan teknik vertikultur adalah jenis tanaman semusim yang memiliki nilai ekonomi tinggi, tinggi tanaman tidak melebihi satu meter dan memiliki perakaran yang sempit. Salah satu tanaman tersebut adalah dari jenis sayuran, antara lain brokoli, bayam, sawi, lombok, terung, tomat dan bawang (Siswadi, 2015).

Bawang merah merupakan salah satu jenis tanaman yang dapat dibudidayakan secara vertikultur. Bawang merah adalah komoditi sayuran yang memiliki peranan penting dalam kehidupan masyarakat baik dilihat dari segi nilai kandungan gizi yang terkandung didalamnya maupun dari nilai ekonomi yang tinggi (Suriani, 2011). Dalam beberapa tahun terakhir, permintaan bawang merah untuk bibit maupun konsumsi mengalami peningkatan sehingga menyebabkan Indonesia mendatangkan bawang merah dari luar negeri untuk memenuhi kebutuhan tersebut. Untuk mengurangi pasokan bawang merah dari luar negeri, meningkatkan produksi dan hasil bawang merah, serta mutu hasil bawang merah harus senantiasa ditingkatkan dengan cara melalui intensifikasi dan ekstensifikasi (Firmansyah dan Sumarni, 2013).

Dalam usaha meningkatkan produtivitas bawang merah yang dibudidayakan secara vertikultur diperlukan media tumbuh yang sesuai serta nutrisi diberikan melalui pemupukan.Terdapat berbagai macam jenis pupuk organik, diantaranya adalah pupuk organik sampah kota. Pupuk organik sampah kota merupakan pupuk yang berasal hari hasil dekomposisi sampah organik sisa rumah dan industry (Rasyid, B. 2012) Tumpukan sampah yang bau, menjijikkan, kotor, serta menjadi sarang bagi lalat dan sumber penyakit dapat diubah menjadi kompos dengan menggunakan sedikit bantuan teknologi sederhana. Selain menjadi komoditas yang berguna juga akan mengurangi polusi lingkungan yang diakibatkan oleh sampah (Murbandono, 2006).

Berdasarkan uraian diatas maka perlu dilakukan penelitian dengan judul Kajian Komposisi Media Tumbuh dan Pupuk Organik Sampah Kota terhadap Produktivitas Bawang Merah dengan Teknik Vertikultur sebagai Alternatif Pemanfaatan Pekarangan dan Limbah Organik di Banyuwangi.

Tujuan dari penelitian ini adalah menerapkan teknik budidaya secara vertikultur pada pekarangan, memanfaakan sampah kota sebagai pupuk organik, untuk mengetahui pengaruh komposisi media tumbuh terhadap produktivitas bawang merah dengan teknik budidaya secara vertikultur, untuk mengetahui pengaruh dosis pupuk organik sampah kota pada produktivitas bawang merah dengan teknik budidaya secara vertikultur, serta untuk mengetahui pengaruh interaksi antara komposisi media tumbuh dan dosis pupuk organik sampah kota pada produktivitas bawang merah dengan teknik budidaya secara vertikultur. 


\section{METODE PENELITIAN}

Penelitian dilaksanakan pada rumah Kooi di lahan percobaan Fakultas Pertanian UNTAG Banyuwangi, Bahan yang digunakan dalam penelitian ini adalah, tanah, cocopeat, arang sekam, cacahan batang pakis, pasir, air, pupuk organik sampah kota, pipa PVC, kayu dan pengikat PVC, kasa, bibit bawang merah. Sedangkan alat yang digunakan dalam penelitian ini adalah tangki semprot, cangkul, parang, penggaris, timbangan, alat oven, gelas ukur, alat suntik, ceret, gergaji, paku, martil, tang, kawat, ember plastik, papan nama, alat tulis, label.

Penelitian yang dilakukan menggunakan metode Rancangan Acak Lengkap (RAL) faktorial dengan empat kali ulangan yang terdiri dari dua faktor yaitu komposisi media tumbuh dan dosis pupuk sampah kota. Faktor komposisi media tumbuh (M) terdiri dari 3 perlakuan, yaitu : $\mathrm{M} 1=$ tanah : pasir : sekam (2:1:1); M2 = tanah : pasir : batang pakis $(2: 1: 1) ; \mathrm{M} 3=$ tanah $:$ pasir $:$ cocopeat $(2: 1: 1)$. Komposisi pupuk organik sampah kota $(\mathrm{P})$ terdiri dari 3 perlakuan, yaitu : $\mathrm{P} 1=$ komposisi pupuk organik sampah kota 25\%; P2 = komposisi pupuk organik sampah kota 50\%; P3 = komposisi pupuk organik sampah kota $75 \%$ Dari dua faktor diatas didapatkan kombinasi perlakuan sebagai berikut : M1 P1 = komposisi tanah : pasir : sekam (2:1:1), komposisi pupuk organik sampah kota 25\%; M1 P2 = komposisi tanah : pasir : sekam $(2: 1: 1)$, komposisi pupuk organik sampah kota 50\%; M1 P3 = komposisi tanah : pasir : sekam (2:1:1), komposisi pupuk organik sampah kota $75 \%$; M2 P1 = komposisi tanah : pasir : batang pakis $(2: 1: 1)$, komposisi pupuk organik sampah kota $25 \%$; M2 P2 = komposisi batang pakis : pasir : sekam $(2: 1: 1)$, komposisi pupuk organik sampah kota 50\%; M2 P3 = komposisi tanah : pasir : batang pakis (2:1:1), komposisi pupuk organik sampah kota 75\%; M3 P1 = komposisi tanah : pasir : cocopeat (2:1:1), komposisi pupuk organik sampah kota 25\%; M3 P2 = komposisi tanah : pasir : cocopeat (2:1:1), komposisi pupuk organik sampah kota 50\%; M3 P3 = komposisi tanah : pasir : cocopeat (2:1:1), komposisi pupuk organik sampah kota 75\%; Data yang diperoleh dari semua parameter pengamatan dianalisis menggunakan sidik ragam (analysis of variance), apabila terdapat perbedaan antar perlakuan maka dilanjutkan dengan uji BNT 5\% dan 1\%. Parameter pengamatan dalam penelitian ini adalah tinggi tanaman $(\mathrm{cm})$ jumlah daun, berat basah (gram), jumlah umbi, diameter umbi $(\mathrm{cm})$.

\section{HASIL DAN PEMBAHASAN}

Berdasarkan pengamatan didapatkan data bahwa pada 10 hst hingga 50 hst jumlah daun terbanyak pada perlakuan M3P1 yaitu komposisi tanah: pasir: cocopeat $=2: 1: 1$ dan pupuk organik sampah kota $25 \%$, sedangkan yang memberikan pengaruh terrendah adalah perlakuan M1P3 (tanah:pasir:sekam = 2:1:1 dan pupuk organik sampah kota 75\%). Hal ini dikarenakan jumlah pupuk organik sampah kota yang terlalu tinggi menyebabkan pertumbuhan tanaman terhambat karena jumlah unsur hara yang berlebihan. Cocopeat dapat digunakan sebagai media pengganti tanah yang aman serta menyehatkan bagi tanaman. Pada dasarnya sifat cocopeat yang mampu menyimpan air dan memiliki pori-pori udara yang menyebabkan tanah menjadi gembur dan perkembangan bibit pada taraf germinasi sangat baik sehingga merangsang pertumbuhan akar baru dengan cepat dan lebat. Perlakuan media tanam berupa cocopeat memberikan pengaruh yang berbeda nyata pada pertumbuhan tinggi tanaman, jumlah daun, umur panen dan saat berbunga pada tanaman dibandingkan dengan perlakuan media tanam yang lainnya (Restiana, 2011). 
Pada pengamatan 60 hst terjadi penurunan jumlah daun pada semua perlakuan. Hal ini dikarenakan bawang sudah mencapai masa panen yang dicirikan dengan sebagian daun yang mengering sehingga jumlah daun berkurang.

Grafik rerata jumlah daun, dapat dilihat pada Gambar 1 sebagai berikut:

\section{RATA-RATA JUMLAH DAUN}

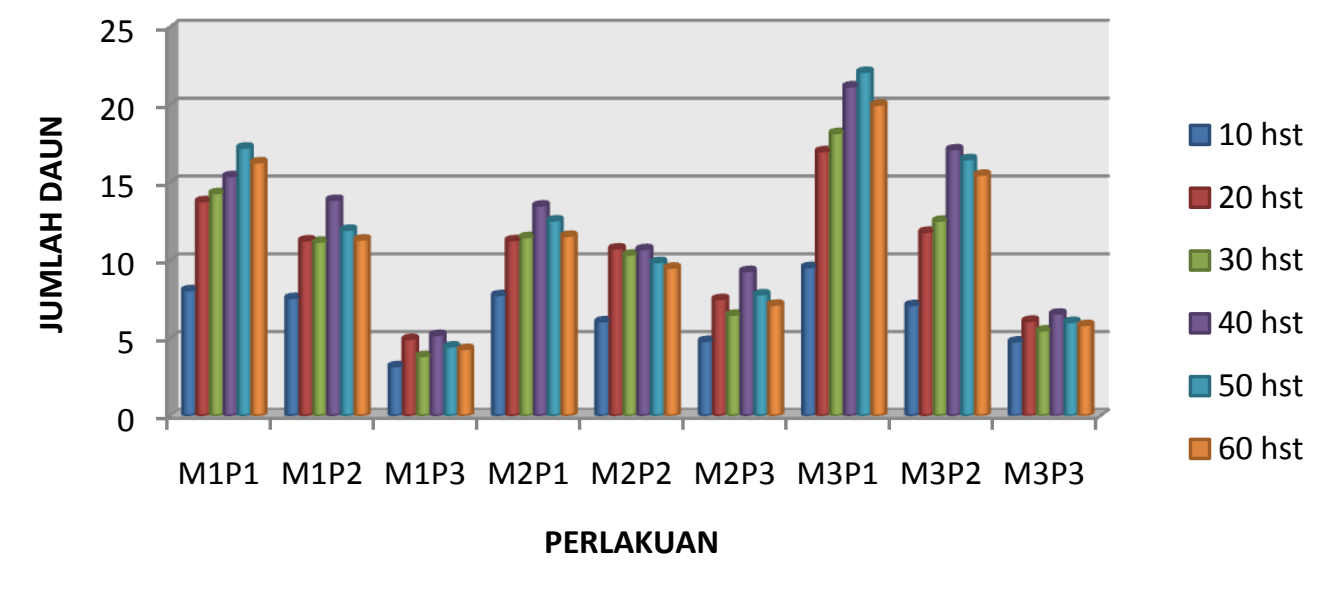

Gambar 1. Grafik rata-rata jumlah daun dalam berbagai perlakuan pada 10 hst, 20 hst, 30 hst, 40 hst, 50 hst dan 60 hst.

Dari Gambar 1, terlihat perlakuan M3P1 merupakan perlakuan yang memperoleh rata-rata jumlah daun tertinggi sebanyak 22,11, pada umur 50 hst, demikian juga untuk tahapan-tahapan pengamatan mulai 10, 20, 30, 40 dan 60 hst, menunjukkan rata-rata jumlah daun terbanyak. Sedangkan rata-rata jumlah daun terendah adalah pada M1P3 sebesar 4,46 pada 50 hst. demikian juga untuk tahapan-tahapan pengamatan mulai 10, 20, 30, 40 dan 60 hst, menunjukkan rata-rata jumlah daun terendah.

Pengamatan tinggi tanaman dapat diketahui bahwa perlakuan M3P1 (tanah: pasir: cocopeat $=2: 1: 1$ dan pupuk organik sampah kota $25 \%$ ) merupakan hasil yang terbaik pada setiap pengamatan tinggi tanaman. Hal ini diduga bahwa komposisi pupuk organik sampah kota $25 \%$ sesuai untuk menunjang pertumbuhan vegetatif tanaman dan komposisi media dengan tambahan cocopeat yang memiliki kandungan trichoderma molds, yaitu semacam enzim dari jamur yang mampu mengurangi penyakit dalam tanah, menjaga tanah tetap subur, gembur serta memudahkan umbi pada tanaman bawang merah tumbuh dengan cepat dan besar.

Berdasarkan hasil analisa laboratorium, pupuk organik sampah mempunyai kandungan Nitrogen $(0,64 \%)$, K2O (1,32\%) dengan kandungan Karbon $(5,29 \%)$ dan rasio C/N (8) serta P2O5 (0,33\%) (Nugraha, 2010). Pupuk organik sampah kota mempunyai kandungan Nitrogen yang lebih tinggi sehingga dapat memicu pertumbuhan vegetatif yang lebih cepat salah satunya adalah tinggi tanaman dan pada komposisi pupuk organik sampah kota $25 \%$ merupakan komposisi yang tepat untuk pertumbuhan bawang merah. 
Data terendah yaitu pada perlakuan M1P3 (tanah:pasir:sekam = 2:1:1 dan pupuk organik sampah kota 75\%). Grafik rata-rata tinggi tanaman, dapat dilihat pada Gambar 2 sebagai berikut :

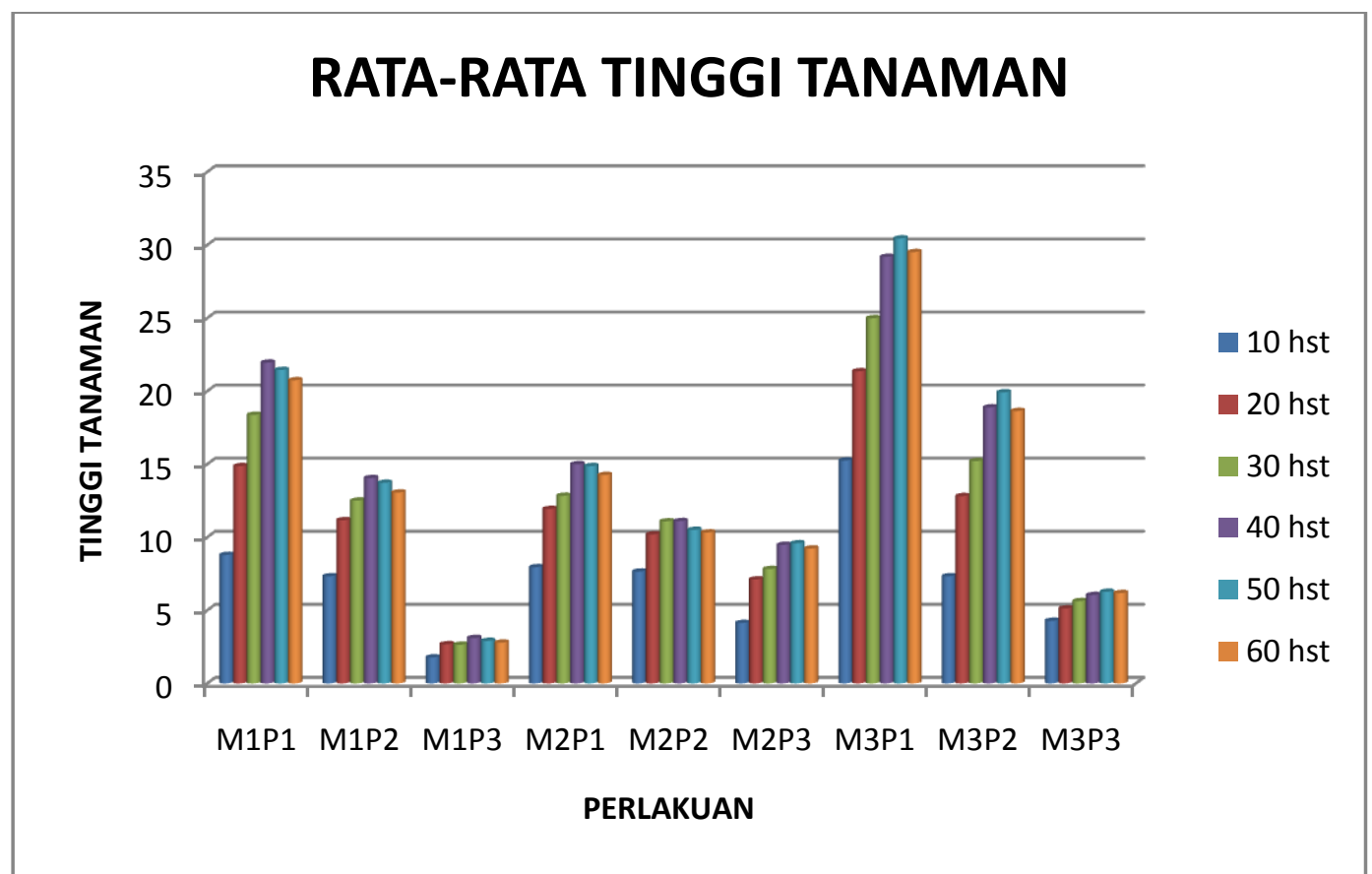

Gambar 2. Grafik rata-rata tinggi tanaman dalam berbagai perlakuan pada $10 \mathrm{hst}, 20 \mathrm{hst}$, 30 hst, 40 hst, 50 hst dan 60 hst.

Dari Gambar 2, terlihat perlakuan M3P1 merupakan perlakuan yang memperoleh rata-rata tinggi tanaman tertinggi sebesar 30,45, pada umur $50 \mathrm{hst}$, demikian juga untuk tahapan-tahapan pengamatan mulai 10, 20, 30, 40 dan 60 hst, menunjukkan rata-rata tinggi tanaman terbesar. Sedangkan rata-rata tinggi tanaman terendah adalah pada M1P3 sebesar 2,91 pada 50 hst. demikian juga untuk tahapan-tahapan pengamatan mulai 10, 20, 30, 40 dan 60 hst, menunjukkan rata-rata jumlah daun terendah. Faktor lingkungan yaitu faktor penentu dalam pertumbuhan dan hasil tanaman. Organisme akan tumbuh optimum serta berkembang dengan baik jika hidup dalam lingkungan tumbuh yang sesuai (Wardhani, et al., 2013). 


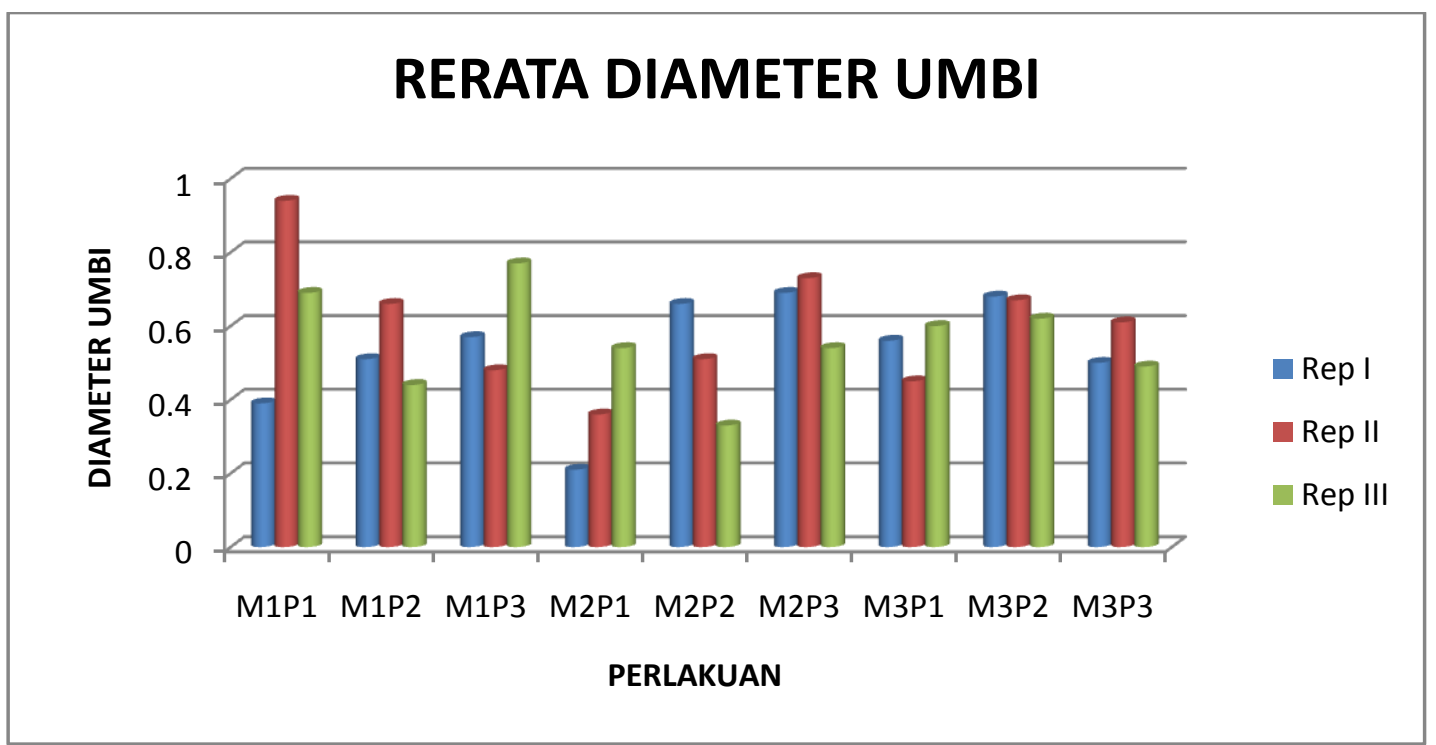

Gambar 3. Grafik rata-rata diameter umbi dalam berbagai perlakuan pada setiap ulangan percobaan.

Dari Gambar 3, terlihat perlakuan M1P1 merupakan perlakuan yang memperoleh rata-rata diameter umbi tertinggi sebesar $0,68 \mathrm{~cm}$ dan diameter umbi terbesar di M1P1 pada ulangan kedua sebesar $0,92 \mathrm{~cm}$. Sedangkan rata-rata diameter umbi terendah adalah pada M2P1 sebesar 0,37 $\mathrm{cm}$ dan diameter umbi terendah di M2P1 pada ulangan pertama sebesar $0,21 \mathrm{~cm}$.

Media sekam mendukung terhadap pertumbuhan umbi bawang merah, karena menurut Singgih (2011), media tanam yang baik untuk bawang merah adalah gembur, mempunyai aerasi yang baik (porous), serta mengandung bahan organik yang tinggi sehingga memicu perkembangan umbi. Sekam sendiri mempunyai fungsi penting sebagai media tanam pengganti tanah. Sekam bersifat ringan, tidak kotor, porous serta cukup cukup untuk menahan air (Septiani, 2012).

Pengukuran rata-rata jumlah umbi tertinggi pada perlakuan M3P1 (tanah:pasir:cocopeat $=2: 1: 1$ dan pupuk organik sampah kota 25\%). Hal ini disebabkan kandungan yang terdapat di dalam media cocopeat mampu membuat tanah menjadi gembur dan banyak kandungan udara yang menunjang banyaknya pertumbuhan umbi. Rata-rata jumlah umbi terkecil adalah pada perlakuan M1P3 (tanah: pasir: batang pakis = 2:1:1 dan pupuk organik sampah kota $75 \%$ ). Grafik rata-rata jumlah umbi, dapat dilihat pada Gambar 4 sebagai berikut : 


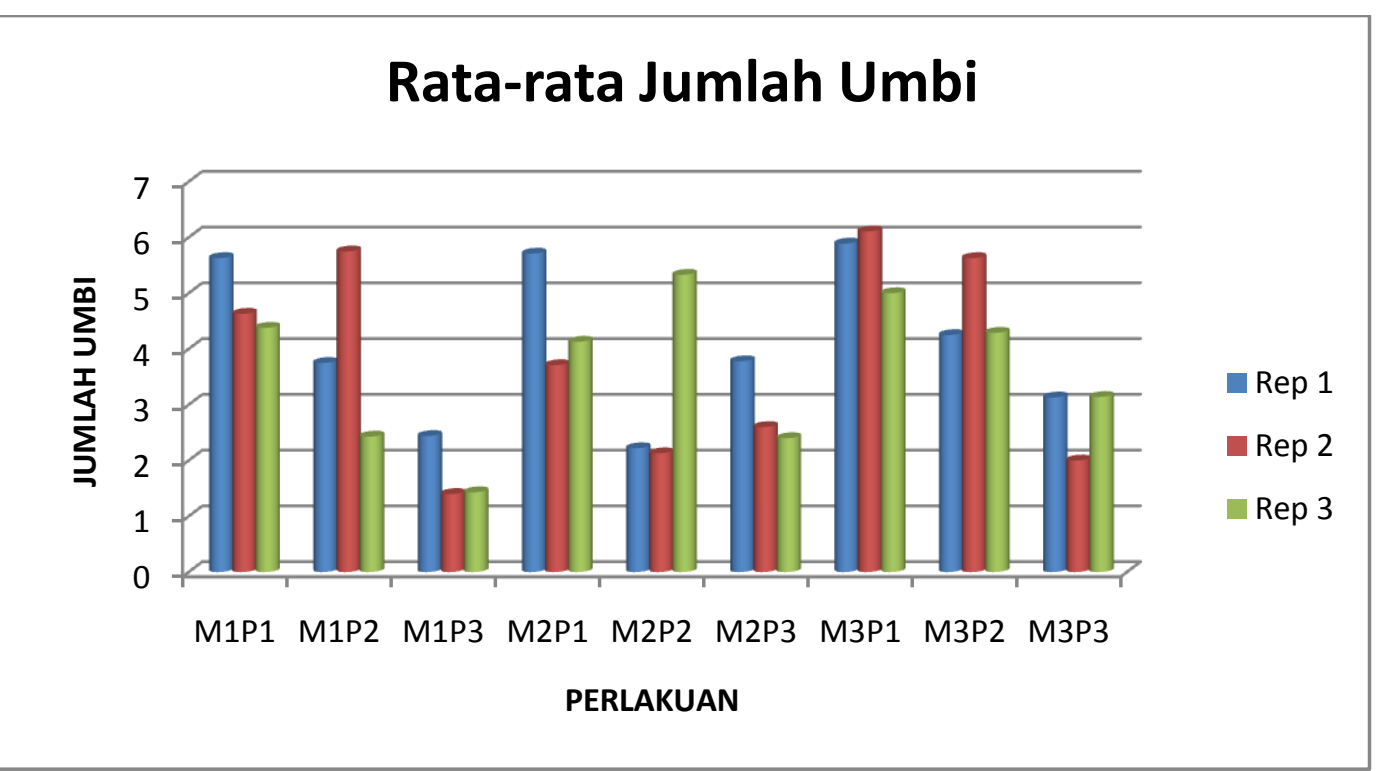

Gambar 4. Grafik rata-rata jumlah umbi dalam berbagai perlakuan pada setiap ulangan percobaan..

Dari Gambar 4, terlihat perlakuan M3P1 merupakan perlakuan yang memperoleh rata-rata jumlah umbi tertinggi sebesar 5,67 buah dan jumlah umbi terbesar juga di M3P1 pada ulangan kedua sebesar 6,11 buah. Sedangkan rata-rata jumlah umbi terendah adalah pada M1P3 sebesar 1,76 buah dan jumlah umbi terendah juga di M1P3 pada ulangan kedua sebesar 1,40 buah.

Hasil perhitungan berat basah menunjukkan bahwa rata-rata berat basah terbesar diperoleh perlakuan M3P1 (tanah: pasir: cocopeat $=2: 1: 1$ dan pupuk organik sampah kota 25\%). Hal ini disebabkan pada parameter berat basah dipengaruhi oleh jumlah daun serta tinggi tanaman dimana pada pada parameter jumlah daun dan tinggi tanaman perlakuan M3P1 memperoleh hasil tertinggi. Selanjutnya grafik rata-rata berat basah, dapat dilihat pada Gambar 5 sebagai berikut : 


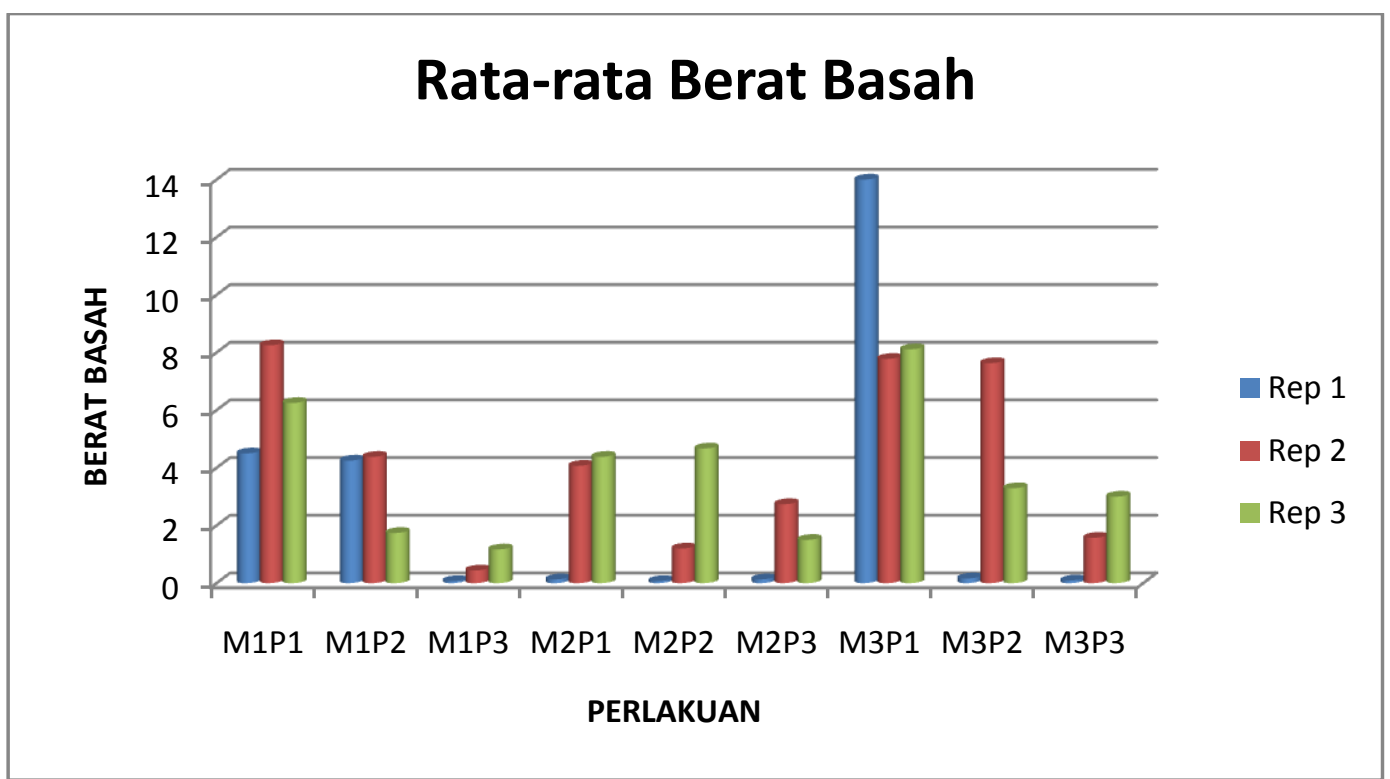

Gambar 5. Grafik rata-rata berat basah dalam berbagai perlakuan pada setiap ulangan percobaan..

Dari Gambar 5, terlihat perlakuan M3P1 merupakan perlakuan yang memperoleh rata-rata berat basah tertinggi sebesar 9,96 gram dan berat basah terbesar juga di M3P1 pada ulangan kesatu sebesar 14 gram. Sedangkan rata-rata berat basah terendah adalah pada M1P3 sebesar 0,56 gram dengan berat basah terendah juga di M1P3 pada ulangan kesatu sebesar 0,07 gram.

\section{KESIMPULAN}

Kesimpulan yang didapat pada penelitian ini adalah (a) Rerata tinggi tanaman dan jumlah daun terbesar diperoleh pada perlakuan M3P1 yaitu komposisi tanah: pasir: cocopeat $=2: 1: 1$ dan pupuk organik sampah kota $25 \%$ pada semua pengamatan; (b) Diameter umbi terbesar diperoleh pada perlakuan M1P1 (tanah:pasir:sekam = 2:1:1 dan pupuk organik sampah kota 25\%); (c) Rata-rata jumlah umbi tertinggi pada perlakuan M3P1 (tanah:pasir:cocopeat $=2: 1: 1$ dan pupuk organik sampah kota 25\%); (d) Rata-rata berat basah terbesar diperoleh perlakuan M3P1 (tanah: pasir: cocopeat $=2: 1: 1$ dan pupuk organik sampah kota 25\%).

Saran untuk penelitian ini adalah (a) Perlu adanya penambahan bahan pendukung pertumbuhan umbi terutama unsur $\mathrm{P}$ dan $\mathrm{K}$ pada pembuatan pupuk kompos sampah kota; (b) Perlu adanya penelitian lanjutan terkait pupuk tambahan guna mendukung produktivitas bawang merah. 


\section{DAFTAR PUSTAKA}

Firmansyah I. dan Sumarni N. 2013. Pengaruh dosis pupuk N terhdap pH tanah, N-total, dan sarapan $\mathrm{N}$ hasil dua varietas bawang merah (Allium ascalonicum $\mathrm{L}$ ) pada Etisol-Brebes Jawa Tengah. Jurnal Hortikultura 23 (4): 358-364, 2013

Murbandono, 2010. Membuat Kompos,Jakarta: Penebar Swadaya.

Nugraha, D. Kandungan Unsur Hara Kompos Dari Campuran Kulit Pisang Dan Effective Microorganisms EM4. 2013. Samarinda. (Online), http:// Diakses 26 Desember 2015

Rasyid, B., 2012. Aplikasi kompos kombinasi zeolite dan fosfat alam untuk peningkatan kualitas tanah ultisol dan produktivitas tanaman jahung. Jurnal Agrisistem, Juni 2012, Vol.8 no.1 ISSN 1858-4330.

Restiana, M.2011. Pengaruh Pupuk Kombinasi Urea - Zeolit - Arang Aktif (UZAA) terhadap pH, Eh, Amonium dan Nitrat pada Tanah Sawah Rancaekek, Kabupaten Bandung

Septiani, D(2012). Pengaruh Pemberian Arang Sekam terhadap Pertumbuhan dan Hasil Tanaman Cabe $\quad$ Rawit. 9 online) (http://hortikulturapolinela.files.wordpress.com/2012/10/dewi. pdf diakses 21 November2014).

Singgih, S (2011),. Sukses Bertanam Sayuran Secara Organik. Angkasa. Bandung.

Siswadi (2015). Pengaruh Macam Media terhadap Pertumbuhan dan Hasil Selada ( Lactucasativa L) Hidroponik.Jurnal Agronomika.Surakarta;Vol. 09 No. 03.

Suriani, N. 2011. Bawang bawa untung. Budidaya bawang merah dan bawang putih. Cahya Atma Pustaka. Yogjakarta.

Wardhani, DK, F Zahro, F Usman, 2012.Arahan Fungsi Lahan berdasarkan Pendekatan Konservasi Tanah Kawasan Pesisir Utara Jawa Timur Kecamatan Ujung Pangkah Kabupaten Gresik Jurnal Tata Kota dan Daerah, 2012 - tatakota.ub.ac.id 